IRA-International Journal of Education \& Multidisciplinary Studies

ISSN 2455-2526; Vol.07, Issue 02 (2017)

Pg. no. 63-72

Institute of Research Advances

http://research-advances.org/index.php/IJEMS

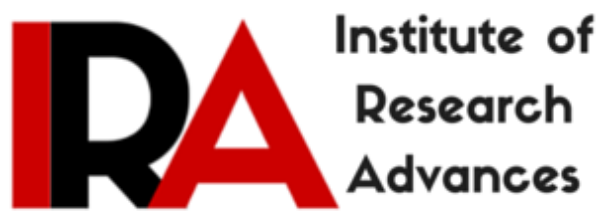

\title{
Driving at Full Employment of Youth of India - Reflecting on Concrete Experience and Abstract Conceptualizing an Action Plan
}

\section{Dr. P Purushothaman}

Retired Professor, Civil Engineering, Vel Tech Technical University-Avadi, Chennai, JBIET, Hyderabad \& Periyar Maniammai University- Vallam, Thanjavur, India.

Type of Review: Peer Reviewed.

DOI: http://dx.doi.org/10.21013/jems.v7.n2.p1

\section{How to cite this paper:}

Purushothaman, P. (2017). Driving at Full Employment of Youth of India - Reflecting on Concrete Experience and Abstract Conceptualizing an Action Plan. IRA International Journal of Education and Multidisciplinary Studies (ISSN 2455-2526), 7(2), 63-72. doi:http://dx.doi.org/10.21013/jems.v7.n2.p1

(C) Author.

\section{(cc) EY-NC}

This work is licensed under a Creative Commons Attribution-Non Commercial 4.0 International License subject to proper citation to the publication source of the work.

Disclaimer: The scholarly papers as reviewed and published by the Institute of Research Advances (IRA) are the views and opinions of their respective authors and are not the views or opinions of the IRA. The IRA disclaims of any harm or loss caused due to the published content to any party. 


\begin{abstract}
The unemployment of youth in India is on the rise. The employability of fresh graduates in India is very low. The general productivity of workforce is also very low. Proper and more interventions, positive actions are required to address the above problems. Solutions may be possible through the four elements of psychological capital development of youth namely, confidence, optimism, perseverance and bouncing back. This paper attempts first mapping the author's own concrete lifelong experience with PysCap elements. Then attempting to abstract conceptualizing an action plan, as a learner. This has given some insights, particularly taking the Indian context of spirituality, large population of unemployed youth and how they could be given proper orientation on industry expectation and developing networks through mentors from industry, as one of the best method of effective skill training is by the employer whether formal or informal training, as the industry can not reject the educated youth, after they complete their education. In addition, the paper presents a learner produced integrated PsyCap schematic diagram and recommends an action plan which can be taken up for further participatory-action research. The paper can be used as a case study learning material for development students as this covers developmental psychology, adult education, traditional apprenticeship, gurukula, formal education, distance mode and self directed learning. The positive PsyCap development is not one time exercise, but spreads from young age to old age, as we can not waste the human resources of our country at this critical time of providing and meeting sustainable development goals.
\end{abstract}

Keywords: full employment, reflection, experiential learning, developmental psychology, sustainable development

\title{
Introduction
}

NITI Aayog (2016) presents that labour productivity is very low and key element in the transformation of India is the creation of a large number of good jobs, which are highly productive and competitive. This also points out to meeting out the global and national requirement of creation of more jobs and sustainable goals: Global unemployment increased from 170 million in 2007 to nearly 202 million in 2012, of which about 75 million are young women and men. The unemployment rate in India is estimated to be approximately 5\% at All India level (2013-14). India's labour force is set to grow by more than 8 million per year. Planning Commission (2013) sets the objective for the $12^{\text {th }}$ planning period for much faster growth in manufacturing to provide employment to the young and increasingly educated population which has high expectations and aspirations. It reports that the unemployment in the period 2009-10 among youth in the age group of 15-29 was in the range of 10.5 to $18.9 \%$. It observes that unemployment is higher among the youth and the educated are looking for better quality jobs. It notes that illiterates have the lowest rate of unemployment, and the rate of unemployment tends to rise with every level of education. It finds rising expectations of the people in terms of quality, equity and access. Sreeradha and Saumya (2016) quote interviewing experts that by virtue of strong foundation, MBAs are more industry-aware and hit the ground running. Aon Hewitt, (2016) find through their studies that companies increasingly identify two key areas of focus recruitment priorities which are all about having a well formed strategy to attract active and passive talent, and relentless focus on communicating a distinguished employer brand. Purushothaman and Suresh (2010) report providing industry awareness training to school children which was effective by using of Science, Technology, Engineering and Mathematics (STEM) education, which they propose could help the children to choose and align to what industry expects from them and prepare themselves with proper attitude and drive to perform. Purushothaman and Suresh (2011d) also report training BE-Later entry students as master masons, that students can be inducted in teaching and training methods, students can in turn train unskilled workers and earn while learning. This could be expected to improve the self-efficacy and the student's performance.

Dello and Stoykova, P., (2015) trained 40 students and professionals as an attempt to replicate positive psychology capital (PsyCap) development and training carried-out by Luthans and others, and to test its durability; they report significant effects of training on students and professionals, and stable over a 
period of one month. Matthijs Steeneveld, (2016) reports that they trained group of employees on two hour micro training sessions, which show improvements. He has given steps involving individuals to try his method. Blom and Saeki (2010) through their survey of Indian industries report that Skill shortage remains one of the major constraints to continued growth of the Indian economy. They suggest that engineering education institutions should: (i) seek to improve the skill set of graduates; (ii) emphasize Soft Skills, (iii) refocus the assessments, teaching-learning process, and curricula away from lower-order thinking skills, such as remembering and understanding towards higher order skills such as analysis and creativity; and (iv) interact more with employers to understand the particular demand for skills in that region and sector. DIRŽYTE (2013) notes that PsyCap predominately focuses on positivity at the individual level, expanding research in the science and study institutions in the USA has also demonstrated positive relations between collective PsyCap and team performance. Further, observes research is needed to test whether PsyCap can be developed via the training model as well as to determine its impact on individual performance. Martin, O'Donohue and Dawkins (2016) recommend examination of multi-level conceptualizations of PsyCap and further investigation of the effects of interventions on individuals and team outcomes. Aspiring Minds (2016) report that there is no significant improvement in employability in the last four years in information technology sectors. They report in software services the current employability is at 17.9\%. They report the need of the hour is to make an exponential impact on employability, which is crucial for India to grow on fast track.

Going through various literatures mentioned above and others, India is facing a major collective negative psychological capital in terms of large proportion of youth, particularly the educated unemployed youth, together with another issue of their performance (productivity) when they get employed. There is urgent need to find ways and means to turn this negative psychosis of the population and the youth to be positive and productive for very goods of national health and progress. This paper attempts reflecting on the authors own life-long learning experience and proposes an intervention education cum training program as a plan.

\section{Reflecting on life-long learning experience of the author Taking stock of self}

I smile and feel happy when I tell myself that nothing is impossible, which also triggers my boyhood amusements-sitting alone as a sentry-boy in our field protecting the crops from cattle, animals and birds ( Purushothaman and Suresh, 2010b): That in future whatever, I want to to do, preparation might lead to success, even on failures, correcting and trying might give success; failures, might only mean not preparing well. Now when I look back at my age of early sixties, this appears to be too sweeping and over confident. And, what a transformation with age and as part of development of self (developmental psychology, Purushothaman, 2008)! Yet in another point of view, with failures or where results are not assuring ( Purushothaman, 2009) and where I consider it is worth to pursue, I sometimes feel overconfident to get going; there would be mood swings as between depression and confidence. Many times, we may not be consciously thinking about this, but acting or dropping issues or tasks, swinging either way, as a bi-polar entity.

At this point, few thoughts flood-in, one is as village children what we play catching dragonfly and making it to hold on to small pebbles, which they will carry any number of times, until, the pebble becomes too big and tiring to hold. The second one is what we were told as part of our evening morale or character building stories, how Anuman had reservations initially to jump-fly to Srilanka and how he gained confidence once he was told about his boyhood when he leapt and caught Sun, thinking it as mango. Third one is about the atman in every one of us. Fourth one, the martial art of varma; its underlying concept that however great one may be he or she can be defeated by appropriate technique and no one is superior or inferior. These school days (gurukula system, Purushothaman, 2011; Purushothaman and Suresh, 2014) inputs together with my early boy-hood reflections got reinforced when I entered the portals of Periyar Maniammai University, that Thanthai Periyar himself is a role model for such positive PysCap development, his own attempt and success on self-respect movement; his saying that he entered into social transformation as no body was coming forward or not doing enough and it was not that he was qualified to bring about the transformation. Such of these 
reflections and associations help us to elevate ourselves in our attempt to take-up any challenge, particularly larger than our individual life size. Together with this keeping in mind Lord Krishna's directive that keep doing one's duty not worried about the results, keep us calm and get going, an essential component to act than just idling (Swami Vivekananda Works, 2001). As any normal individual and recollecting our past experience, thoughts, directives, we can recompose or regroup ourselves to take-up anything appreciable to us.

\section{Positive Attribution}

Having come from an agrarian family from one of a backward district of Tamilnadu and having inducted into agricultural practice right from boy-hood, productivity was one concept, which we would always be talking and thinking ( Purushothaman, 2010b). In addition there would be age related competition as between working in the field and wanting to play with other children-peers out in the streets. However, quest on productivity has remained even for now, thinking for ever. Anything big or impossible in near future, economists would call it Utopian and to my part, I have conceptualised an Utopian theory of full employment, although informal, based on Maslow's hierarchy of needs, but as a template of human wants or needs or utilities, sum of those all needs contributing a production or work function of humanity. The big dream is, if all of us go productive, how that state would be, prosperous and peaceful, satisfying all our needs, all are fully employed, satisfying our basic needs, social needs, power needs working both positive and negative including the natural calamities and each individual or group or collectively, the whole nation, self - actualizing, maximizing the gains or the ends. The limited resources are only in our minds and in theory, but working from where we are towards enhancing our productivity many-fold. The youth are of specific interest, how I was taught or instructed that as a farmer's son, I should not sleep in the day-time and I should not feel bad to enter mud-fields. This also had impacted my professional life and the concept of full employment at individual level, the self directed rules are, don't stay at home without a job, or when there is no job, create your own job, whether you have immediate financial returns or not. I saw on a path of continuous professional development, so that at any point of time, I could perform without hitch. On one hand we have idea of full employment and another hand, we have direction of not idling at home, particularly for youth. Indians as Vivekanandar says, are spiritual and we are all gifted by that positive asset with hope and positivism. Reaching a state of full employment particularly for youth may not be difficult for a country, whose population is spiritual and the dream may not be so distant!

\section{In order to succeed}

Working towards full employment is first self-employment for me and for us, who choose to work on it (helping ourselves, Swami Vivekananda Works, 2001). For elderly persons, it is youth development and for youth it is paving for their future. Engaging youth and informing or educating or training youth on productivity and achievement appears to be very important, as I reflect on my confidence derived from boy-hood work experience in the agricultural fields in the formative days. I practically never had the fear of loss of a job, could place myself in any job including my own consulting or social service, mostly kept myself engaged even during tough times, I have had a very unlikely placements in more than eighteen organizations and my present occupation of professional development of students and fresh graduates as a social entrepreneur is one such engagement. If we reflect on this situation, it is very interesting that however the present occupation is not paying or not having good returns (financial) it is worth continuing and however I am supported by family, similar situation is arising in the case of youth, even if they are unemployed, they are supported by parents till such time they could. But, when they are left without jobs, the negativism is too great in terms of not developing professional or craft skills and idling or wandering into devils workshops. Engaging the youth and creating opportunities for professional or crafts skills are very essential not only in the formative days, but also after graduation towards full employment of youth in the country. The country is facing so many problems and there are enough number of sustainable developmental goals, not only for our country, but for whole world. There is job for all us to do and we will all work together and make progress, which will be inclusive of all, male and female; poor and rich; old and 
young. This would be the vision and mission towards full employment, peace and prosperity to all in the country. This is not an individual job, but a collective one. We have to start from where we are, taking up small action, participatory research and moving up, replicating successful instances to a large scale.

\section{Bouncing back}

Earlier attempts, particularly, training of youth on security workforce and on mason skill development as a social entrepreneur at my village failed ( Purushothaman, 2009). When I analyse, my involvement was divided, the expectation of youth was different or I could not mobilize the youth. Or, we could list any number of reasons. But two questions, I ask myself: Can I afford to fail? What shall I do, if I fail? This appears to be more like fight or flight survival situation! And, in the larger interest, can we fail, in providing full employment at least for youth? And, if we fail, what course do we have? Or, are we satisfied with present level of unemployment and under-productivity? What shall we do? I am tempted to think in terms of our collective interest, the collective self, of individuals and as a whole nation, what is our self-efficacy, hopes, positivism and holding onto our goals, goal congruence! The ups and downs, the travails of our life, through ages have instituted a culture of life style that we are passionate of human nature, kindness, hopeful and positive of our future, and we keep working calm and quiet with our certain understanding of our capacity as human beings! When we carefully look at poor families, we see the parents carefully raising their children to a higher level of satisfaction than their present level, that, we can proudly say that the older generations realise their own dreams through their younger generations, in a way an iteration or improving their own state of well-being (fig-1). This also reflects an iterative or bouncing back process of humanity of pedagogy of oppressed as reflecting on objects of oppression resulting in necessary engagements of liberation; this pedagogy will be made and remade (Paulo Freire 1993). In democratic countries like ours, poverty, unemployment and under-productivity can be seen as objects of oppression.

\section{Internalizing the concepts of positive PsyCap}

I am on a learning curve as I am trying to assimilate and accommodate (Terry Heick, 2014) the concepts of PsyCap. Reflecting on my own experience and relating have helped and has given some hope while trying to understand the concepts as a learner. The spiritual component of creating positive PsyCap is enormous, particularly the calmness and the determination that one would pursue his or her goals, with hope and positivism and determination. The industry standard, ISO quality PDCA (Plan, Do, Check and Act) model is also very interesting as an iterative process of achieving professional excellence. An attempt is made creating a model incorporating above concepts from other schools of philosophies as a learner produced material for reflection (fig-1). 


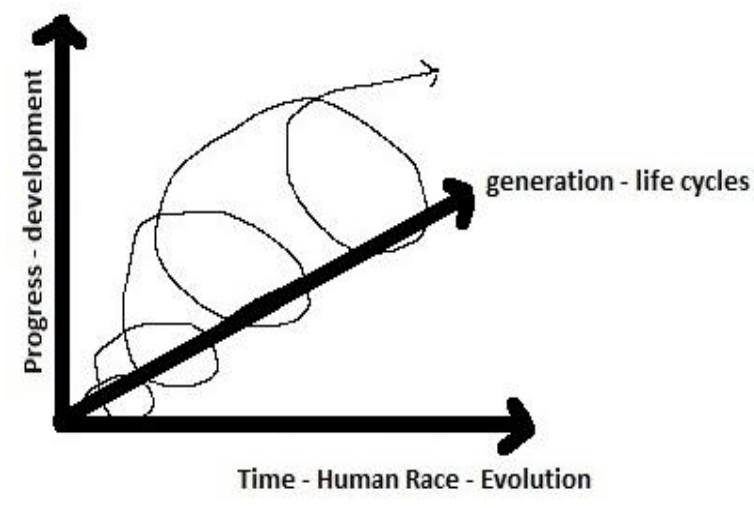

Schematic diagram showing integrated PsyCap model

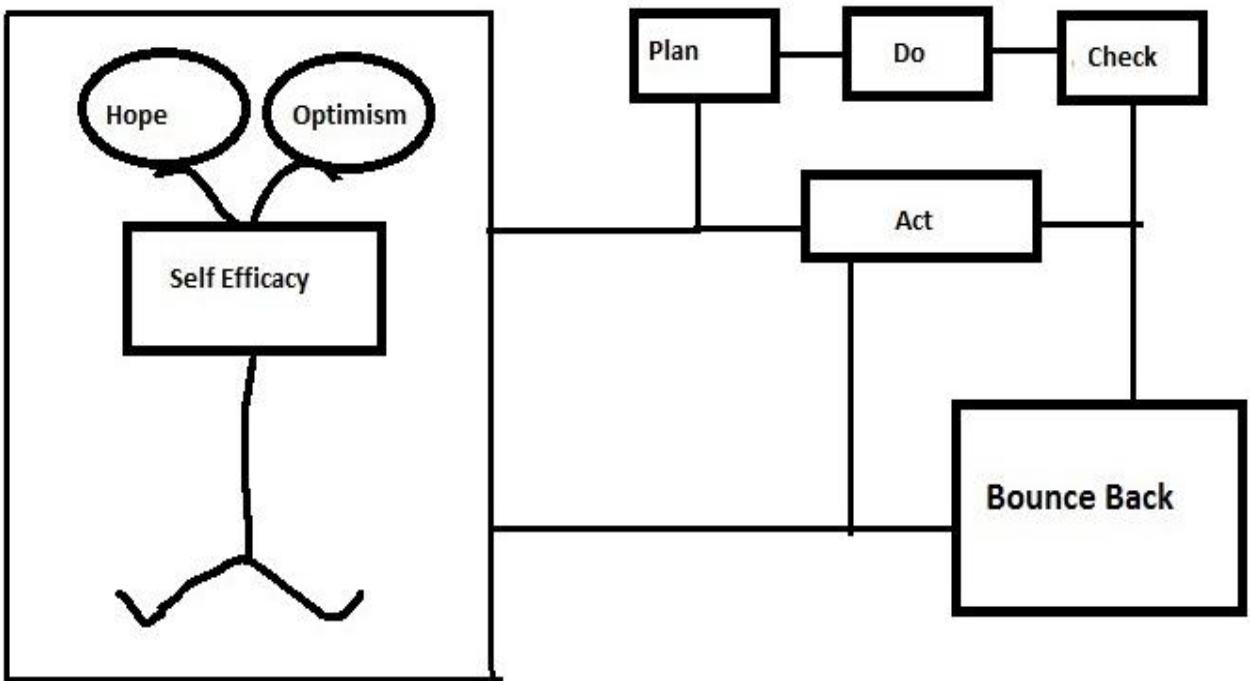

Figure-1, Schematic diagram showing integrated PsyCap model

\section{Discussions}

When I first came across the definition of PsyCap, I had my own aversions and fears (self efficacy), however, I held on to it and made an attempt (however inferior, it may be with hope and positivism) to explore further, attempting to theorize based on my own life-long concrete experience and by abstract conceptualizing (Kolb \& Kolb,2005; Singh, 2010). This reflection resulted in identification and relating to hope and positivity with our traditional spiritual experience (Purushothaman, 2011) which forms base of our self-efficacy of Indians in general, although a over generalization based only on my experience. It may also be noted of Swami Vivekananda's Works, (2001) on personality development that work itself is having a different meaning, work through freedom and love are his messages. Interestingly, the introduction chapter mentions about faith in oneself, positive thoughts, attitude towards failures and mistakes; self-reliance and renunciation and service. The work nature as understood by Swami Vivekananda is such that there is work or job for all of us, and by doing there would be peace, calm and prosperity for not only to the individuals, but to the whole world.

The formative empirical research on training during post tsunami relief works and further research resulted in identifying the barriers of skill development and self-efficacy of rural youth to receive any training. As a solution an ice breaking training was implemented. This training was suitable as an induction cum motivation training of unskilled workers (Purushothaman, 2014, Purushothaman and Suresh 2011a, 2011b, 2011c, 2011d). This training was designed by integrating with social learning theory and advocating epitomizing and spiralling techniques, as a possible solution to address the large size unskilled workforce in India, who toil at the bottom of the pyramid. Unlike the routine job situation in corporates, the skill development of millions of people in India is a herculean task and 
India is already on Mission mode to address this problem and every citizen is required to participate in this effort. We have already seen mentoring of engineering students in many institutes (IISc, IITs \& IIMs) and VelTech technical institute claims student mentoring as one of its best practice ( Purushothaman, Suppiah and Suresh 2016). They propose integrating field practice with curriculum for better results and enhancing of employment of students. Middleton, Ziderman and Adams (1993) report that skill trainings are effective when provided by employer and managers go for the second best choice than training them. Purushothaman (2014) has shown that there is trade-off in providing training and meeting the cost, so only very few get trained in the country. Wang et al. (2010) observe that informal training is not inferior; informal or formal training, but well planned and implemented are effective. The problem faced in India on skill development and employment are very complex and very large size in scale, particularly when we consider the large scale un-employability of youth and under productive workforce, including high proportion of unskilled workers. Though, the employment rate is high with less educated the self efficacy to receive training is very low and the expectation of educated is very high with low confidence, whereas, the industry reject most of them as unfit for employment. There may not be an easy solution to all these problems, which require evolving feasible solutions and examining them through action - participatory research. Whereas, the general population with rich cultural background with high hopes and positivism based on spirituality could keep the youth to look ahead at a bright future with full of opportunities created by us and by the youth themselves. The positive psychological capital will have to be ingrained in every one of us young or old to mobilize vibrant and productive workforce. This is a possibility as we start looking at formative days of our children, as the confidence I gained working in the agricultural fields in the early ages, contributing and earning is immense.

\section{An action plan as a feasible solution or recommendations}

Pedagogy of oppressed gives a direction that reflecting on conditions or objects of oppression, theory of oppression and theory of revolution shall be made (Paulo Freire,1993, Purushothaman 2010). If we take unemployment, under productivity, unskilled large workforce, poverty as object of oppression, which reflect lack of full employment thus large pressure on livelihood, although, the oppressor is not that evident, require us to find solutions by different ways and means, which in the first place, we require the courage to think big and differently, which have bearings on our own collective selfefficacy as a nation, that we require to boost-up ( Swami Vivekananda Works, 2001). We have to act, tirelessly and with confidence, hope and right frame of mind, positive. Full employment in India could easily be self-respect, good or decent earning and good quality of life and could be a sathyagragha, a spiritual belief of calmness and determination to achieve our goals, congruent and united. The proposal is largely based on my own life-long experience taking it as a concrete experience, reflecting and abstract conceptualizing, which may work with few groups or to a large group, only taking actions, implementation and action research would tell us or offer course corrections. The learner produced integrated PsyCap (fig-1) is interesting as a professional approach of ISO - 9001 (2000) quality system PDCA cycle is added to the PsyCap model, but identifying hope and positivism as attainable through spirituality; and, identifying the whole PsyCap as an instant of time in the space of human race or development, after all to continue to work in a company, one has to survive, the survival instincts now have shifted to work situations at offices. That this development is not one time training or involvement, but on a continuum as life long exercise. At old age, we may bounce back, or retire or rest with hope and positivism, that youth would take care of themselves, however, the national agenda is not yet over.

1. Right from eighth standard school students can be given industry awareness and created work experience starting from small or simple line jobs in the industry or as may be applicable to socially productive work experience (Purushothaman, 2014).

2. This experience can be spiralling-up with training and progress of the student creating positive work experience (Purushothaman, 2014)

3. This may be developed through industry-institute tie-ups and each student or group tied-up with mentors to help, guide to develop confidence and motivation ( Purushothaman, Suppiah 
and Suresh, 2016).

4. This can be continued from schools till the students come out as graduates and get placed in suitable jobs or create their own.

5. Suitable opportunities could be created for unemployed youth whether educated or educated to further acquire work experience whether paid or not towards full professional development or crafts skills.

6. The above plan can be taken up by various action and participatory researchers in small scales, design and develop such that large scale replication could be taken-up ( Purushothaman, 2016).

\section{Conclusion}

Reflection is a tool for both learners and teachers, and helps in understanding issues on hand (Paulo Freire, 1993). This paper reflecting on one's own life-long experience mapping to elements of PsyCap gives ample opportunity to assimilate and accommodate the concepts on a learning curve (Terry Heick, 2014). As such this would be useful to development students as a case study. This exercise has also resulted in a learner produced material a model integrating PsyCap, PDCA and Human race or sustainable development. The Indian special context of spirituality is also attempted to be seen as contributing to hope and positivism. Towards driving at full employment, there is good scope for PsyCap development right from school children as a feasible pathway. However this requires further research, particularly action research. We have to consider that positive PsyCap development is not one time exercise, but spreads from young age to old age.

\section{References}

1. Aon Hewitt, (2016), People Matters Study - Decoding Hiring Trends in India 2016, Retrieved from http://www.aon.com/india/attachments/Hiring\%20Trends\%20A4\%20size\%20low\%20res\%20 6-7-16.pdf

2. Aspiring Minds (2016), NATIONAL EMPLOYABILITY REPORT, ENGINEERS, Annual Report 2016, retrieved from http://www.aspiringminds.com/sites/default/files/National\%20Employability\%20Report\%20\%20Engineers\%20Annual\%20Report\%202016.pdf

3. Blom, A.; Saeki, H., (2010), Employability and Skill Set of Newly Graduated Engineers in India, FICII Higher Education Summit 2009 and at World Bank presentations, draft, retrieved from $\quad$ http://www.npiu.nic.in/PDF/Mentoring\%20and\%20Audting/B Employbility $\% 20$ and $\% 20$ Skill $\% 20$ set $\% 20$ of $\% 20$ newly $\% 20$ graduated $\% 20$ engineers $\% 20$ in $\% 2$ OIndia.pdf

4. Dello Russo, S.; Stoykova, P., (2015), Psychological Capital Intervention (PCI): A Replication and Extension, Human Resource Development Quarterly, abstract, retrieved from http://dx.doi.org/10.1002/hrdq.21212

5. DIRŽYTĖ, A., (2013), Research on positivity and psychological capital at science and study institutions in the usa, intelektine ekonomika intellectual economics 2013, vol. 7, No. 3(17), p. 389-395, retrieved from https://www.mruni.eu/upload/iblock/943/IE-13-7-3-09.pdf

6. ISO - 9001 (2000) International Standard, Quality management Systems - requirements, Reference No. ISO 9001:2000(E)

7. Kolb, A.Y. and Kolb, D.A (2005), [Alice Y. Kolb and David A. Kolb (2005)] The Kolb Learning Style Inventory-Version 3.1, Technical Specifications, Experience Based Learning Systems, Inc. Case Western Reserve University

8. Luthans, F.; Avey, J.B.; Avolio, B.J.; Norman, S.M. and Combs, G.M. (2006), Psychological capital development: toward a micro-intervention, Journal of Organizational Behaviour, J. Organiz. Behav. 27, 387-393 (2006), retrieved from www.interscience.wiley.com

9. Martin, A.; O'Donohue, W. and Dawkins, S., (2016), Psychological capital at the individual 
and team level: Implications for job satisfaction and turnover intentions of emergency services volunteers, retrieved from http://www98.griffith.edu.au/dspace/bitstream/handle/10072/53389/79480_1.pdf;sequence=1

10. Matthijs Steeneveld, (2016), Psychological Capital: Training the 4 Positive Capacities retrieved from https://positivepsychologyprogram.com/psycap/

11. Middleton J., Ziderman A., Adams A. V. (1993) Skills for productivity, Vocational Education and training in developing countries, Published by World Bank, Oxford University Press

12. NITI Aayog, 2016, Jobs, Growth and Coastal Economic Zones, Sustainable Development Goals, retrieved from http://niti.gov.in/content/jobs-growth-and-coastal-economic-zones and http://niti.gov.in/content/goal-8-promote-sustained-inclusive-and-sustainable-economicgrowth-full-and-productive

13. Paulo Freire (1993) Pedagogy of Oppressed, Translated by Myra Bergman Ramos, Penguin Books, England

14. Purushothaman, P., (2008), Non Violence, A Potential terrorist transforming into a social change manager / activist, National seminar on Non Violence : A tool for induced change, Mahatma Gandhi National Institute of Research and Social Action, Hyderabad, 28-29 January, 2008

15. Purushothaman, P., (2009), Action Research: Self Employment Opportunities in Vocational Training in Construction Industry, national Workshop on Skill Development for Unemployed Youth, Workshop Papers, School of Entrepreneurship and Extension, National Institute for Micro, Small and Medium Enterprises (ni-msme), Hydrabad, 29th June, 2009

16. Purushothaman, P., (2010), Evolving theories of oppression and revolution in reduction of poverty in India, International Journal of Action Research and Engineering to Eradicate Poverty, Vol.1., Issue.3., Dec-2010, pp- 153-161

17. Purushothaman, P., (2011), My Journey towards searching a god, Atheism - an alternative culture, abstract of the seminar papers, World atheist conference 2011, Periyar Maniammai University, Thanjavur, 8th Jan 2011, retrieved from https://drive.google.com/file/d/0BxSkYgXjLXqUZmUwZjdjYWEtMWI1ZC00MTAwLTkxN jItYzk3NGQzZmY5NTVj/view?usp=sharing

18. Purushothaman, P., (2014), A study on effectiveness of training of construction workers in Tamilnadu, $\mathrm{PhD}$ thesis submitted to Madras University, Chennai, Tamilnadu, India

19. Purushothaman, P., (2016), Professional development of students and fresh graduates, presentations: retrieved from https://drive.google.com/file/d/0BxSkYgXjLXqUXzlEb0pneEg3WUk/view?usp=sharing and, https://drive.google.com/file/d/0BxSkYgXjLXqUVHZrT1o3X0NXckE/view?usp=sharing

20. Purushothaman, P.; Suppiah, S.; Suresh, ESM., (2016), Design and development of curriculum for B.Tech. civil engineering students with leading choices in multi-disciplinary areas, annual technical volume of interdisciplinary coordination committee of the institution of engineers (India) for the year 2016-17, accepted for publication

21. Purushothaman, P.; Suresh, ESM., (2010a) ,Industry Awareness and Industry Orientation Training to School Children in Rural area, a case study, IJAREEP,1,1,5-17,2010,GCT78, Chennai

22. Purushothaman P, Suresh ESM, (2010b), pin ar mun ar aanathu - a reflection on traditional apprenticeship in agrarian family, long version written in Tamil, retrieved from https://drive.google.com/file/d/0BxSkYgXjLXqUSkxpeXNLZS1QUG8/view?usp=sharing

23. Purushothaman P and Suresh ESM, (2011a), A Case Study On A Short Term Ice Breaking And Motivational Training Given To Female Workers From Rural Background To The Skill Level Of Assistant Mason, International Journal of Action Research \& Engineering to Eradicate Poverty Vol.No. 02, Issue No. 02, February 2011, pp-218-248

24. Purushothaman P and Suresh ESM, (2011b), Our Picture Book and Learning Through Reflection, Journal of Engineering, Science And Management Education, Vol.-4, Issue-III, Jul-Sept 2011, pp-186-188

25. Purushothaman P and Suresh ESM, (2011c), Training of youth and workers from tsunami 
affected areas through participative methods in building technologies, The Indian Journal of Technical Education, Vol.No. 34, Issue No. 03, September 2011, pp-1-8

26. Purushothaman $P$ and Suresh ESM, (2011d), Training of BE civil engineering lateral entry students as mason instructors- a case study, International Journal of Action Research \& Engineering to Eradicate Poverty Vol.No. 02, Issue No. 04, April 3011 , pp- 337-343

27. Purushothaman P, Suresh ESM, (2014), Reflecting on pedagogical issues of e-dub-ba-a of Sumeria linking to our present times, Journal of engineering, science and management education, Vol-7(II) 136-141, 2014, ISSN 0976-0121

28. Singh N K (2010), Adult Education, Saurabh Publishing House, New Delhi

29. Sreeradha, D. B.; Saumya, B., (2016), India's top campus recruiting companies of 2016 , retrieved from http://economictimes.indiatimes.com/jobs/indias-top-campus-recruitingcompanies-of-2016/articleshow/54202192.cms

30. Terry Heick, (2014), The Assimilation Vs Accommodation Of Knowledge, retrieved from http://www.teachthought.com/learning/assimilation-vs-accommodation-of-knowledge/

31. Swami Vivekananda Works, (2001), Personality Development (compilation), Advaita Ashrama, ISBN 81-7505-224-4

32. Wang, Y., Goodrum, Paul M., Haas, Carl T., and Glover, Robert W. (2008) Craft Training issues in American Industrial and Commercial Construction, Journal of Construction Engineering and Management, ASCE, Volume-134, No-10, pp795-803 